\title{
A deep seismic reflection line in the Danish Central Graben
}

\author{
LONE KLINKBY, NIELS BALLING \& JØRGEN LIBORIUSSEN
}

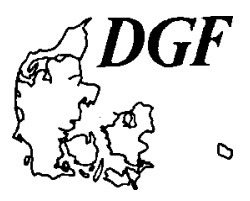

\begin{abstract}
Klinkby, L., Balling, N. \& Liboriussen, J.: A deep seismic reflection line in the Danish Central Graben. Bulletin of the Geological Society of Denmark, Vol. 44, pp. 151-159. Copenhagen, 1998-02-28.

https://doi.org/10.37570/bgsd-1998-44-09
\end{abstract}

Results are presented from a deep seismic reflection line, recorded to 16 seconds travel time, across the Coffee Soil Fault in the southern part of the Danish Cen-tral Graben. Data processing has been focused on the deeper parts of the sedi-mentary sequences, the crystalline crust and the crust-mantle boundary. Depth migration is performed down to $15 \mathrm{~km}$ depth, and time migration is performed on the entire section. The Coffee Soil Fault is clearly imaged as a normal fault dipping about $45^{\circ}$ from about 2.5 to $9 \mathrm{~km}$ depth. Interpretation of the sedimen-tary sequences is constrained by well data and shows an almost uniform $2 \mathrm{~km}$ thick unit of post-chalk deposits. The thickness of the Mezosoic sequences is to a large extent controlled by faulting and highly influenced by movements of Zechstein salt. They exceed $4 \mathrm{~km}$ of thickness in the halfgraben immediately west of the Coffee Soil Fault. Large block-faulted pre-Zechstein units of more than $2 \mathrm{~km}$ thickness are seen indicating a total depth of at least $8 \mathrm{~km}$ to the crystalline basement. The crystalline crust is generally non-reflective. Around 11 seconds two-way travel time (about $28 \mathrm{~km}$ depth) reflectivity interpreted as the crust-mantle boundary (Moho) is observed. Comparison with other deep seis-mic profiles across the Central Graben is taken to indicate a local crustal thin-ning by a factor of 1.5 associated with graben formation by extension.

Key words: Deep seismic reflections, Central Graben, data processing, Coffee Soil Fault, crustal thinning.

L. Klinkby[lkl@geoserver1.aau.dk]\& N. Balling, Department of Earth Sciences, Geophysical Laboratory, University of Aarhus, Finlandsgade 8, DK-8200 Arhus $N$, Denmark. J. Liboriussen, Marsk Olie og Gas AS, Esplanaden 50, DK-1263 København K, Denmark. September Ist, 1997.

Seismic profiles across the basin areas in the central North Sea are numerous, and the interpretation of the sediments in the Central Graben is well controlled by well data down through the Jurassic sequences. The deeper parts of the basin and their crustal-scale structure are less well known. However, deep seismic reflection profiling has the potential of giving detailed information for interpretation of the pre-Jurassic levels. Deep seismic profiles crossing the Central Graben in the central and southeastern part of the North Sea are shown in Figure 1. Normal-incident lines NSDP85 and SNST 83-7 trending SW-NE, acquired prior to 1990 (Klemperer \& Hobbs, 1991), image the crust beneath the graben and the surrounding highs, and the combined near vertical and wide angle profile SALT (Barton, 1986) has given information on crustal thick- ness. In 1993, as part of the MONA LISA project two reflection profilestrending almost east-west were shot with subsequent wide-angle recordings along one of the lines, which gives valuable new information on the thickness and structure of the crystalline part of the crust (MONA LISA Working Group, 1997).

The $50 \mathrm{~km}$ long seismic line (DK88-43) presented here was collected in 1988 by Mærsk Olie og Gas AS as part of an exploration seismic survey, but with a recording length of 16 seconds. The line is trending WSW-ENE in the Salt Dome Province across the border fault of the Central Graben (Coffee Soil Fault) towards the western part of the Ringkøbing-Fyn High (Fig. 2). Recording parameters are listed in Table 1. As velocity and density contrasts in the crystalline crust generally arise from metamorphic and tectonic 


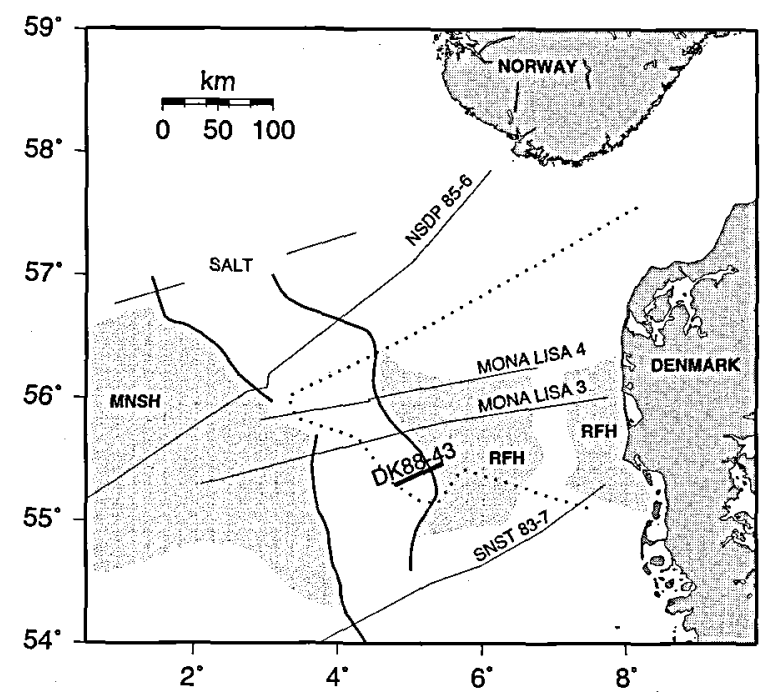

Fig. 1. The central North Sea with the deep seismic lines mentioned in the text. The approximate outline of the Central Graben is shown, and the surrounding major basement highs are shaded: $\mathrm{MNSH}=$ Mid North Sea High, RFH = Ringkøbing-Fyn High.
Table 1. Recording parameters for seismic line DK88-43.

processes, reflectors are inherently different from reflectors in the sedimentary sequences. Therefore processing of deep seismic profiles is slightly different from processing of exploration seismic data (Klemperer, 1989). In the North Sea seismic signals frequently become strongly attenuated in the deep basin areas, and furthermore coherent noise from near-surface structures is prominent.

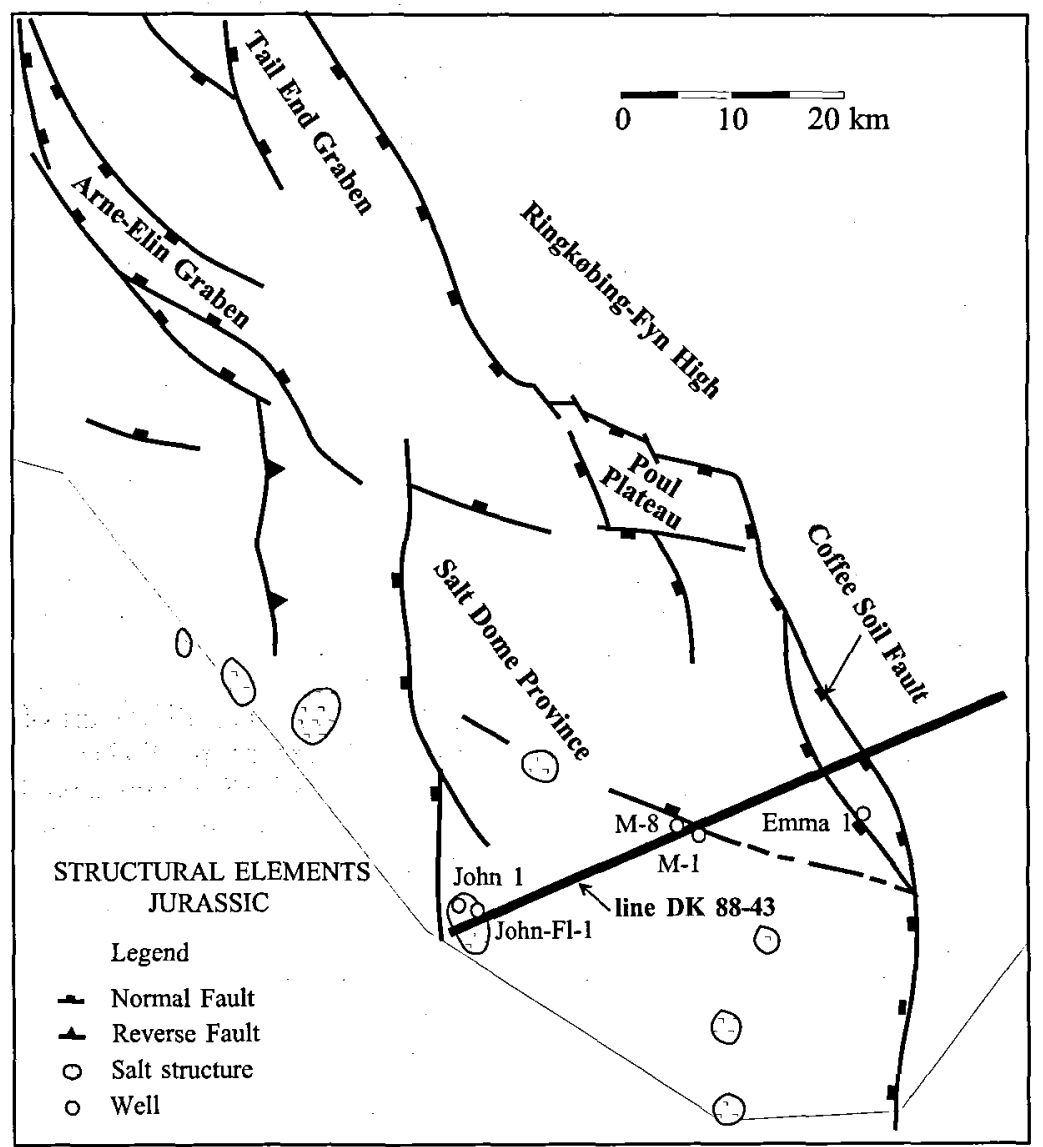

Fig. 2. Position of the deep seismic reflection line DK88-43 in relation to structural elements (after Møller, 1986 ) in the Salt Dome area in the southern part of the Danish Central Graben. Wells used for the interpretation of the sedimentary sequences are shown. 
Fig. 3. Seismic line DK88-43

showing the extent of the coherent noise problem before noise attenuating data processing. Note the reflection around $11 \mathrm{~s}$ TWT, around $30 \mathrm{~km}$ distance.

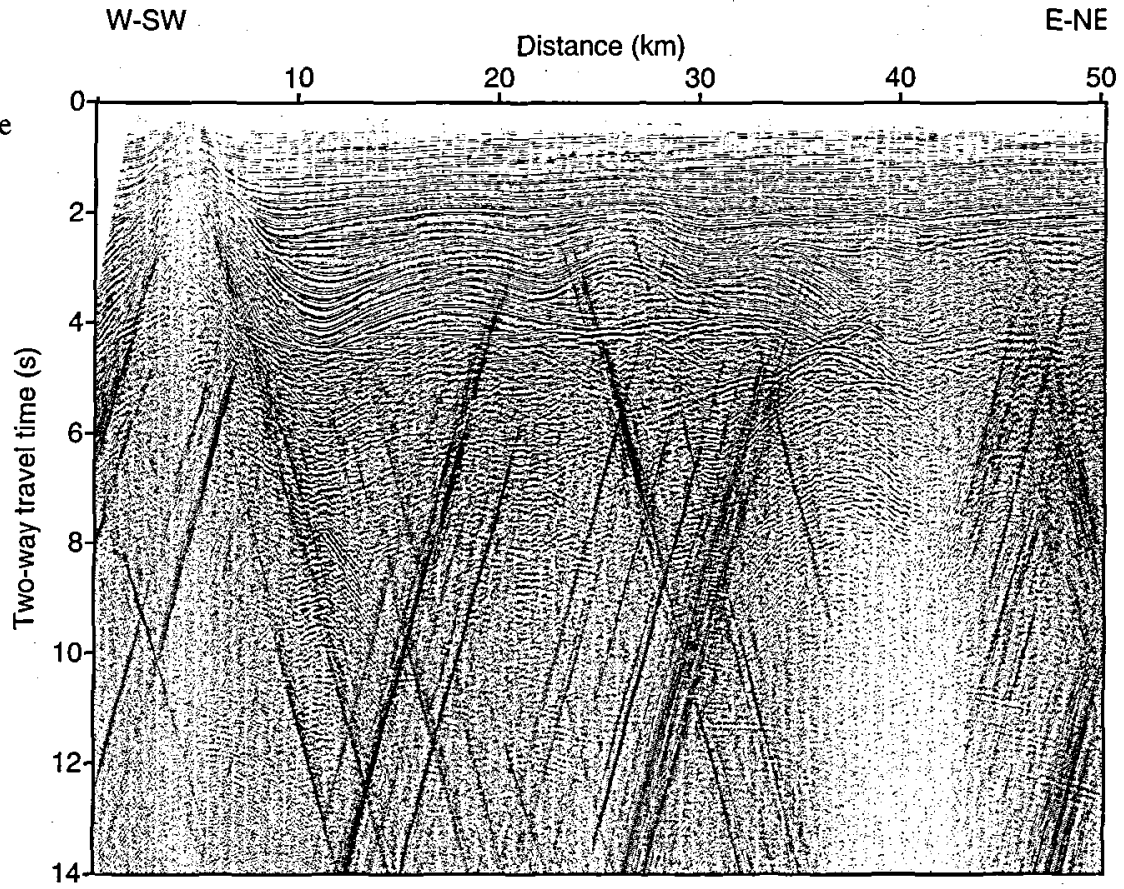

\section{Structural setting}

The North Sea area forms an intra-continental basin. Upon Caledonian closure of the Iapetus and Tornquist oceans, Baltic basement to the east was sutured with Laurentic basement to the northwest and a Gondwana derived terrane (referred to as Eastern Avalonia) to the south (e.g. Berthelsen, 1992, Pharaoh et al., 1995). The crystalline basement in the central and southern North Sea region is determined from deep wells as low-grade Caledonian metamorphic rocks with ages around 440-450 my (Frost et al., 1981). Details in position of the borders and transition zones to Precambrian terranes are subject to current investigations (e.g. MONA LISA Working Group, 1997). During the Late Palaeozoic shelf conditions existed, and the oldest sediments penetrated by wells in the North Sea are red sandstones and limestone of Devonian age (Ziegler, 1990). The E-W trending Ringkøbing Fyn (RFH) - Mid North Sea High (MNSH) acted as a barrier between a northern and a southern sedimentary basin. Rotliegendes red-beds and Zechstein salt were deposited during transition to shallow marine conditions

Permian(?) extensional regimes caused opening of the Southern Atlantic Ocean and initiated a rifting phase in the North Sea. Continued rifting resulted in formation of N-S to NW-SE trending Graben structures crossing the structural highs. The Tail End Graben bordered by the Coffee Soil Fault towards the RFH is a principal structural element in the Danish part of the North Sea and was mainly formed during major differential subsidence in the Mezosoic. The main rifting phase in Late Jurassic time gave way to more than $4 \mathrm{~km}$ of shale-dominated deposits in the deepest part of Tail End Graben (Vejbæk, 1992). Active rifting ceased in the late cretaceous and early tertiary where deposition of chalk was associated with a global sea level rise. The tertiary represents a phase with rapid regional subsidence, and former structural highs became buried beneath uniform sequences of clastic sediments. Movements of Zechstein salt have locally influenced thickness and outline of the Mesozoic and tertiary units significantly.

In the Danish Central Graben the Post-Permian sedimentary column thickens from $3 \mathrm{~km}$ in the western part to $7 \mathrm{~km}$ towards the deepest part along the Coffee Soil Fault where more than $8 \mathrm{~km}$ of sediments are seen in places (Vejbæk \& Britze, 1994). Deep seismic profiles across the North Sea combined with gravity modelling show crustal thickness decreasing from a regional value of more than $30 \mathrm{~km}$ to less than $25 \mathrm{~km}$ below the grabens (Holliger and Klemperer, 1990). This observation combined with knowledge of the thickness of the sedimentary units shows marked crustal thinning during post-Carboniferous extension phases in the North Sea (Klemperer \& Hurich, 1990).

\section{Data processing}

Prestack processing of the data has focused on attenuation of coherent noise from near surface scatters. Problems with coherent noise from near surface scatters are well known from the North Sea (Newman, 
Table 2. Processing parameters for seismic line DK88-43.

1984), and for deep seismic data the problems are severe as the near vertical signal decays faster than the noise (Fig. 3). The standard way of suppressing noise in deep seismic data is array simulation (trace mixing in the shot and receiver domain). However, this causes some smearing and loss of continuity of the wanted signal. The Dip Move Out (DMO) processor is normally used in areas with dipping reflectors to account for the loss of resolution caused by common depth point smearing (Deregowski, 1986). This is hardly a concern in deep seismic data, but as the DMO processor gently filters out coherent noise without distortion of the primary signal (Klinkby \& Pedersen, in press), it has been used for the present data set. Another well-known problem in seismic data from the North Sea is short and long period multiples generated by interfaces with high reflection coefficients e.g. the top of the Chalk Group. As the crystalline basement is not very reflective, this problem is primarily seen on structural highs. The radon transform separates reflectors by their difference in velocity and zerooffset time. It has been used to suppress the long period multiples, and as a positive side effect it also attenuates the coherent noise (Noponen \& Keeney, 1986). The multiples and the coherent noise were modelled and then subtracted from the data in order to minimize filter effects. Processing parameters are listed in Table 2.

Depth migration was performed down to $15 \mathrm{~km}$ using interval velocities from nearby wells (Nielsen \& Japsen, 1991). For the deepest sediments and the upper part of the crystalline crust velocities have been constrained by information from MONA LISA lines $\mathbf{5 0}$ $\mathrm{km}$ to the North. The velocity field is smoothed spatially and in depth before migration in order to mini- mize unwanted effect of processing due to insufficient resolution of details in the velocity field. This causes some lack of accuracy in the image of reflectors close to the Coffee Soil Fault and in the exact outline of the salt structures. The salt structures are furthermore highly 3-dimensional in shape, and 2-dimensional near vertical seismic data lack the ability of resolving details of such features (Sundsbø \& Megson, 1993). For the deep crystalline crust no velocity information is available on this profile. Closely spaced wide angle recordings have been made as part of the MONA LISA project (MONA LISA Working Group, 1997). Velocity information from these data (Nielsen et al., 1997) has been used as a basis of selecting a simple onedimensional velocity model with an interval velocity of $6.6-6.8 \mathrm{~km} / \mathrm{s}$ for the deep crust. The entire profile has been migrated with a fast Stolt time migration (Pedersen \& Jacobsen, unpublished), which has allowed a considerable amount of testing of velocities suited for migration. The example shown in Figure 5 was migrated using velocities reduced by $20 \%$ for the deep crust. It is a well-known experience that some velocity reduction is generally needed for migration of deep seismic data. Depth conversion of the migrated data has been made with the relatively detailed velocity model for the sediments combined with the more simple velocity distribution for the deeper part of the crust.

\section{Geological interpretation}

The top $10 \mathrm{~km}$ of the depth migrated profile is displayed in Figure $4 a$ and, with an interpretation superimposed, in Figure $4 \mathrm{~b}$. The geological interpretation is controlled by data from nearby wells (Nielsen \& Japsen, 1990) and supported by information from other seismic profiles in the area (Vejbæk \& Britze, 1994; Britze et al., 1995a,b,c). The profile shows that large halo-kinetic movements have influenced the thickness and depth to the Mesozoic sequences. In the westernmost part a prominent dome of Zechstein salt has intruded the Tertiary sequences and reaches depths of $750 \mathrm{~m}$ (Britze et al, 1995d). The profile crosses the Dan field around $27 \mathrm{~km}$ distance. The outline of the Zechstein salt structure in this area is based on a detailed interpretation by Sundsbø \& Megson (1993). The area between 30 and $35 \mathrm{~km}$ distance is known as the Alma structure, and the interpretation is not easily constrained by well data or other available information. The pillow structure may be due to salt accumulation from within the Triassic sequences. These formations do contain salt of some thickness (Jacobsen, 1982).

The Coffee Soil Fault is clearly imaged in the eastern part of the profile with a dip of approximately $45^{\circ}$ from about 2.5 to $5 \mathrm{~km}$ depth. Deeper in the section, from 5 to $9 \mathrm{~km}$ depth, it appears to steepen and is only partly seen as a reflected event. The fault seems to 


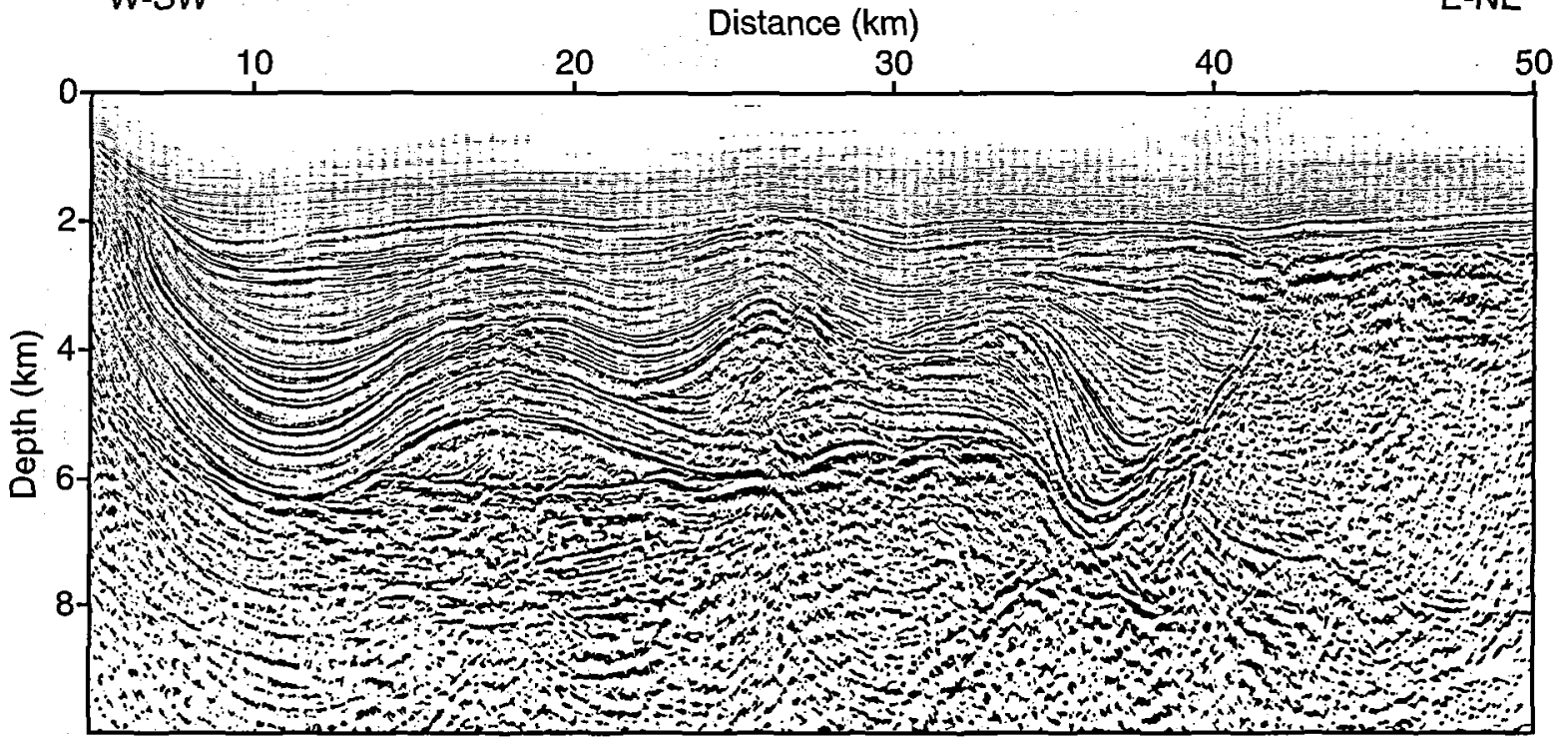

W-SW

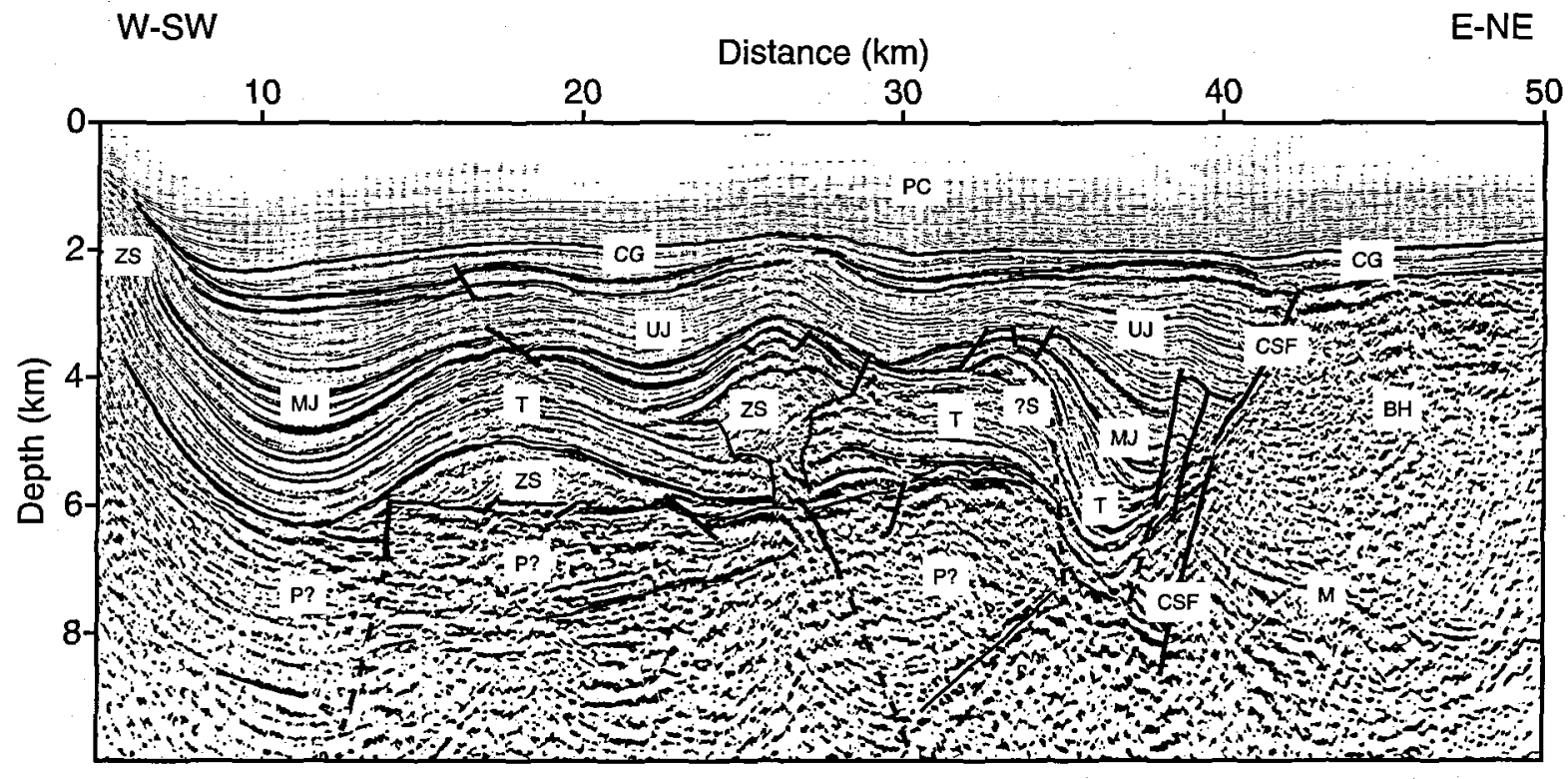

Fig. 4. (a) The depth migrated seismic line DK88-43 shown to $10 \mathrm{~km}$ depth. Vertical exaggeration 2. Horizontal scale is kilometre distance along the profile; (b) As (a) but with interpretation superimposed. $P C=$ Post-Chalk, $C G=$ Chalk Group, UJ=Upper Jurassic, MJ=Middle Jurassic, T=Triassic and Lower Jurassic, ZS=Zechstein Salt, S=possibly Triassic Salt, P?=Undifferentiated Palaeozoic, BH=Basement High, CSF=Coffee Soil Fault, M=Multiple. Lower Cretaceous is seen between the Chalk Group and the Upper Jurassic sequences. Note the dipping appearance of the multiple due to lateral changes of the velocity field. 


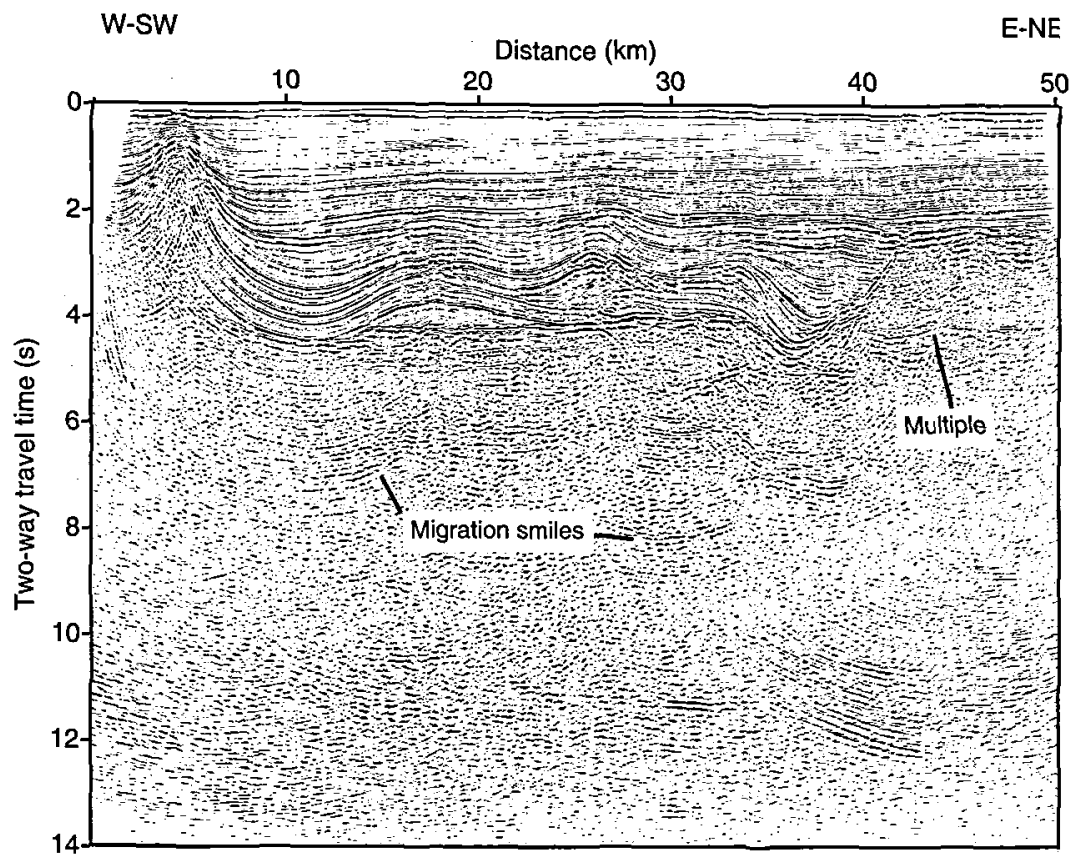

Fig. 5. Seismic line DK88-43 migrated using velocities reduced by $20 \%$ for the deep crust. See text and Table 2 for explanation. Scale is $1: 1$ for velocities of 5.5 $\mathrm{km} / \mathrm{s}$. Moho-related reflectivity is seen between 10 and $12 \mathrm{~s}$ TWT from 10 to $45 \mathrm{~km}$ distance. The long period multiple on the RFH is labelled along with some of the migration smiles from leftover coherent noise.

have been active as a normal fault throughout the Mezosoic until the Early Cretaceous, and possibly in the Late Palaeozoic as well. There is no indication that the fault should be listric, but the steepening may be caused by the spatial smoothing of the velocity field prior to migration. Furthermore, the steep part of the fault as well as other steeply dippings faults are not easily imaged by the near-normal incidence data and are primarily seen as zones of truncated reflections. On the basement high, east of the Coffee Soil Fault, only sequences younger than Early Cretaceous are interpreted. In the Tail End Graben the Mesozoic sequences are faulted and seen to a depth of $7.5 \mathrm{~km}$ around $37 \mathrm{~km}$ distance along the profile.

The Quaternary and Tertiary sequences (postDanien) are rather uniform and interpreted as a c. 2 $\mathrm{km}$ thick cover. The thickness of the Chalk Group varies between 200 and $600 \mathrm{~m}$ and is primarily controlled by salt movements, except close to the Coffee Soil Fault where it is thinned and indicates synchronous inversion tectonics. The Lower Cretaceous is between 100 and $200 \mathrm{~m}$ thick and onlaps the Jurassic sequences close to the basement high, on which it is absent (Vejbæk, 1986). The Jurassic succession is interpreted as only $1 \mathrm{~km}$ thick over the central salt dome and up to $3 \mathrm{~km}$ thick in the Tail End Graben where its thickness is highly controlled by movements along the Coffee Soil Fault. It is subdivided in a primarily Upper Jurassic succession (Møller, 1986), which is more than $2 \mathrm{~km}$ thick in the graben, and a primarily Middle Jurassic succession (Møller, 1986) with a maximum thickness of $1000 \mathrm{~m}$. Inversion tectonics have caused up-doming at around $38 \mathrm{~km}$, but forma- tion thicknesses seem to be undisturbed implying Jurassic deposition before the inversion. Furthermore, the thickness of the Jurassic sequences is clearly affected by salt movements observed as thickening around 12 and $22 \mathrm{~km}$ and thinning around 25 and 33 $\mathrm{km}$ distance. The succession shown as Triassic includes the earliest Jurassic sediments as well (Michelsen et al., 1987) and is interpreted as rather uniform about $2 \mathrm{~km}$ thick, but intruded by Zechstein salt in the central salt dome area. This uniformity implies that the halo-kinetic movements were initiated after deposition of these formations. Pre-Zechstein Palaeozoic sequences of more than $3 \mathrm{~km}$ thickness are seen as large block-faulted units to a depth of $9 \mathrm{~km}$.

The migrated time section (Fig. 5) shows a zone of sub-horizontal reflector segments, along the profile from 10 to $45 \mathrm{~km}$ distance, from 10 to 12 seconds two-way travel time (s TWT). It is interpreted as reflectivity from the crust-mantle boundary (Moho). The clear reflection around $32 \mathrm{~km}$ distance at $11.3 \mathrm{~s}$ TWT corresponds to $28 \mathrm{~km}$ after depth conversion. The dipping events seen further to the east at up to $12.5 \mathrm{~s}$ TWT are not fully migrated to their correct positions due to the simple velocity function used. Migration with slightly different velocities causes these events to be imaged further up-dip in a position just to the east of the sub-horizontal reflector segments. The crystalline crust between the deepest sediments and the Moho shows no significant reflectivity. This section is contaminated by migration smiles from leftover coherent noise and some long-period multiples. The limit of signal penetration, defined as the travel time of no further decrease in amplitude strength, is be- 


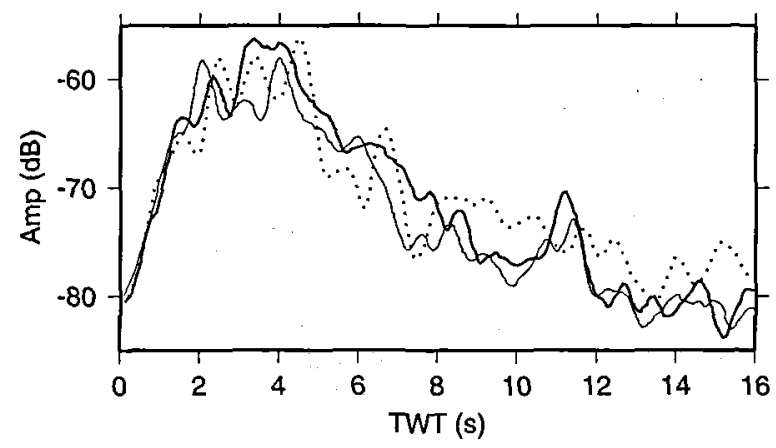

Fig. 6. Examples of amplitude decay curves for the unmigrated final stack. Each curve represents a sum of 9 adjacent traces. Dotted curve: $15 \mathrm{~km}$ distance, thick curve: 25 $\mathrm{km}$ distance, thin curve: $35 \mathrm{~km}$ distance along the profile. Moho reflectivity is seen at 25 and $35 \mathrm{~km}$ distance between 10 and 12 s TWT.

yond $12.5 \mathrm{~s}$ TWT, and decay curves show distinct increase in amplitude strength around $11 \mathrm{~s}$ TWT (Fig. $6)$.

\section{Crustal thinning in the Central Graben area}

The crust beneath the Central Graben and adjacent areas is, in general, seen with very little reflectivity in deep seismic data (e.g. Klemperer \& Hobbs, 1991, MONA LISA Working Group, 1997.) The reason for this can be an actual absence of reflectors. However,

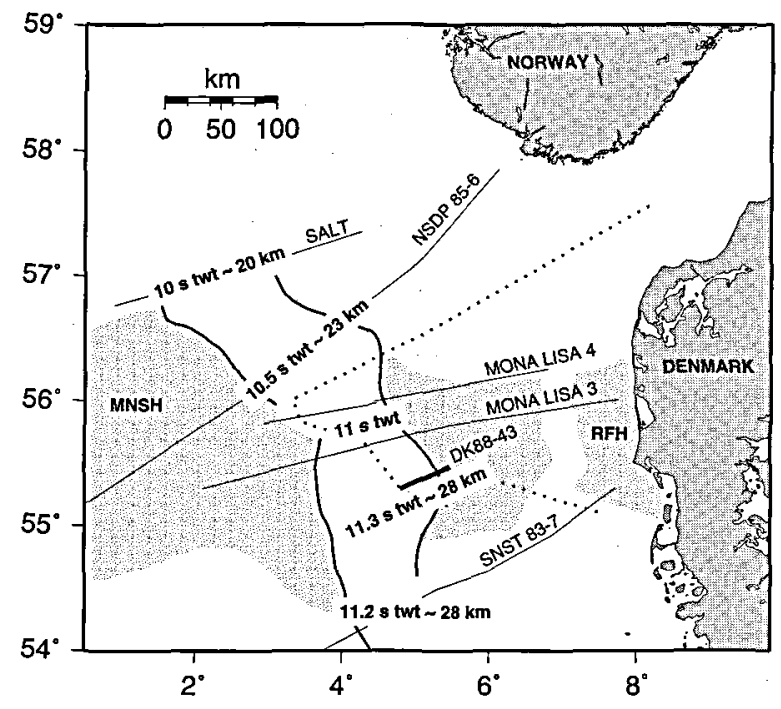

Fig. 7. Compilation of observed two-way travel times (twt) in seconds and obtained depth $(\mathrm{km})$ to the crust-mantle boundary in deep seismic profiles across the Central Graben. The approximate outline of the Central Graben is shown, and the surrounding major basement highs are shaded. any possibly weak, reflective structures present are difficult to resolve due to the combination of the attenuation of the near-vertical signal by the thick sedimentary sequences and the high noise level from the near-surface scatters. Even so, the crust-mantle boundary has been interpreted from other deep seismic profiles across the Central Graben. Some of these results are seen in Figure 7. Holliger \& Klemperer (1990) converted travel times observed in 3 deep seismic lines across the Central Graben to depth. Velocity models primarily from the wide angle data of the SALT-profile in the northern part of the central North Sea were used (Barton, 1986). In combination with gravity modelling, the depth to Moho in and around the Central Graben has been deduced. The SNST 83-7-profile to the south in the Dutch part of the Central Graben shows hardly any deep crustal reflectivity, but the Moho is observed at $11.2 \mathrm{~s}$ TWT just east and west of the graben (Klemperer \& Hobbs, 1991). A total crustal thickness of $28 \mathrm{~km}$ is modelled in the graben area. To the North, in the British and Norwegian parts of the Central Graben, the NDSP 85-6-profile shows Moho reflectivity at $10.5 \mathrm{~s}$ TWT (Klemperer \& Hobbs, 1991), and a depth of $23 \mathrm{~km}$ is obtained. From the SALT-profile farther north near-vertical data show Moho reflectivity at $10 \mathrm{~s}$ TWT at the western part of the graben. In combination with the wide angle data, a depth of 22 $\mathrm{km}$ to the crust-mantle boundary below the centre of the graben is obtained. In the Danish sector the MONA LISA lines 3 and 4 show reflectivity around $11 \mathrm{~s}$ TWT just east of the graben (MONA LISA Working Group, 1997; Nielsen et al., 1997). The crust here is stated to be at least $5 \mathrm{~km}$ thinner than on the surrounding highs, where a value of $33 \mathrm{~km}$ is given.

Subsidence and crustal thinning in the North Sea area may be explained by pure shear (e.g. White, 1989; Nielsen \& Balling, 1990) or simple shear rifting models (e.g. Vejbak, 1992). Both models use the assumption that the volume of the crystalline part of the crust is preserved during stretching, i.e. no crustal material is added, and nothing is removed. Holliger \& Klemperer (1990) and Klemperer \& Hurich (1990) quantified the combined effects of post-Carboniferous strecthing in the central North Sea as the ratio of a $32 \mathrm{~km}$ thick reference crust (a regional estimate for crustal thickness before stretching) to the residual thickness of the thinned crust (the local values of the thickness from base Permian to Moho). The amount of crustal thinning can be accordingly estimated along line DK88-43. The top of the pre-Zechstein basement is seen between 5.8 and $7.5 \mathrm{~km}$, and with the inferred depth of $28 \mathrm{~km}$ for Moho a local value of $21 \mathrm{~km}$ thickness is obtained for the thinned crust. With the value of $32 \mathrm{~km}$ of thickness for the crust before stretching, which is supported e.g. by the MONA LISA deep seismic data from the RFH (MONA LISA Working Group, 1997), crustal thinning by a factor of 1.5 is obtained for the Danish part of the Salt Dome Province. For line SNST83-7 further south and for line NSDP 85-6 
to the north (Fig. 7), stretching factors of 1.5 and 2 respectively, are obtained (Holliger \& Klemperer, 1990). Areas of thick accumulations of sedimentary sequences in the Central Graben are thus found to be closely associated with areas of significantly thinned crystalline crust. These observations support the view of crustal extension and lithospheric stretching as dominating processes in graben formation (e.g. Wood \& Barton, 1983, Klemperer \& Hurich, 1990, Nielsen \& Balling, 1990).

\section{Conclusions}

Regional subsidence in the southern part of the Danish Central Graben, as shown by the sedimentary sequences of the DK88-43-profile, has taken place at least since Late Palaeozoic. This is in agreement with other observations from the area (e.g. Michelsen, 1982). The Coffee Soil Fault is imaged as a marked normal fault from 2.5 to about $9 \mathrm{~km}$ depth dipping about $45^{\circ}$ to the west and possibly steepening slightly at depth. The differential subsidence culminated in the Late Jurassic, and the thickness of the Jurrassic deposits is more than $3 \mathrm{~km}$ in the Tail End Graben. The thickness of the total post-Carboniferous sequences exceeds $7.5 \mathrm{~km}$. Deep reflections interpreted to originate from the crust-mantle boundary are observed around $11 \mathrm{~s}$ TWT corresponding to $28 \mathrm{~km}$ depth. Very little seismic reflectivity is observed from the crystalline part of the crust. A thickness of $21 \mathrm{~km}$ for the crust below base Permian is estimated, and by assuming a regional crustal thickness value of $32 \mathrm{~km}$ before rifting we obtain crustal thinning by a factor of 1.5 since the Late Palaeozoic. This is taken to suggest equivalent crustal extension by a factor of 1.5 for the Danish part of the Salt Dome Province. These results agree well with the regional observations outlined by Klemperer \& Hurich (1990) for the entire North Sea region. They found stretching factors between 1.5 and 2 in the Central Graben areas adjacent to the present study area.

\section{Acknowledgement}

We wish to thank Mærsk Olie og Gas AS for data courtesy. Morten Wendell Pedersen, Århus, is acknowledged for help and continuous discussions on data processing and for making his fast migration routine available to us. Lars Nielsen, Århus, kindly helped with crustal velocity data for migration and depth conversion. Trine Dahl Jensen, Copenhagen, gave valuable comments on data processing and the final migration. Ole Valdemar Vejbæk and John Korstgård carefully reviewed the manuscript and suggested improvements.

\section{Dansk sammendrag}

Der præsenteres resultater fra et $50 \mathrm{~km}$ langt dybseismisk refleksionsprofil registreret til $16 \mathrm{~s}$ over Coffee Soil forkastningen i den sydlige del af den danske Central Grav. Processeringen af data fokuserer på de dybere dele af de sedimentære sekvenser, den krystalline skorpe og skorpe-kappe grænsen. Der er foretaget dybdemigration til $15 \mathrm{~km}$ og tidsmigration af hele sektionen. Coffee Soil forkastningen, der afgrænser Central Graven mod øst mod RingkøbingFyn Højderyggen, ses tydeligt som en normal forkastning hældende omkring $45^{\circ}$ mod vest fra 2.5 til $9 \mathrm{~km}$ dybde. Tolkningen af sedimenterne er støttet af oplysninger fra boringer $i$ området og viser en næsten ensartet $2 \mathrm{~km}$ tyk enhed af sedimenter aflejret efter Danien. Store tykkelsesvariationer af de Mesozoiske sekvenser kontrolleres af forkastningsaktivitet og bevægelser af Zechstein salt. I halvgraven umiddelbart vest for Coffee Soil forkastningen overstiger mægtigheden $4 \mathrm{~km}$. Blokforkastede enheder med tykkelser over $2 \mathrm{~km}$ ses under Zechstein salt. Der er således mere end $8 \mathrm{~km}$ til den krystalline skorpe, der generelt ikke er reflektiv. Omkring $11 \mathrm{~s}$ tovejstid, svarende til $28 \mathrm{~km}$ dybde, ses reflektivitet der tolkes som skorpekappe grænsen (Moho). Sammenligning med andre dybseismiske profiler over Central Graven indikerer en lokal fortynding af skorpen med en faktor på 1.5 knyttet til ekstension i forbindelse med dannelsen af gravstrukturen.

\section{References}

Barton, P. J. 1986. Comparison of deep reflection and refraction structures in the North Sea. In Barazangi, M. \& Brown, L. (eds) Reflection Seismology: A global Perspective. American Geophysical Union, Geodynamic 13, 297-300.

Wood, R. \& Barton, P. 1983. Crustal thinning and subsidence in the North Sea. Nature 302, 134-136.

Berthelsen, A. 1992. Mobile Europe. In Blundell, D. J., Freeman, R. \& Mueller, S. (eds) A continent revealed: The European Geotraverse. Cambridge University Press, 1132.

Britze, P., Japsen, P. \& Andersen, C. 1995a, b, c, d. Geological map of Denmark. 1:200.000. The Danish Central Graben.'Base Chalk' and the Chalk Group. 'Base Cretaceous' and the Cromer Knoll Group. 'Base Upper Jurassic' and the Upper Jurassic. 'Top Chalk' and the Post Chalk Group. Danmarks geologiske Undersøgelse Map Series 48, 49, 50, 47.

Deregowski, S. M. 1986. What is DMO? First Break 4, 724.

Frost, R. T. C., Fitch, F. J. \& Miller, J. A. 1981. The age and nature of the crystalline basement of the North Sea Basin. In Illing, L. V. \& Hobson, G. D. (eds) Petroleum geology of the continental shelf of north-west Europe. London: Institute of Petroleum, Heyden and Son, 4357.

Holliger, K. \& Klemperer, S. L. 1990. Gravity and deep seismic reflection profiles across the North Sea Rifts. In 
Blundell, D. J. \& Gibbs, A. G. (eds) Tectonic evolution of the North Sea Rifts. Oxford University Press, 82-100.

Jacobsen, F. 1982. Description of the formations. Triassic. In Michelsen, O. (ed.) Geology of the Danish Central Graben. Danmarks geologiske Undersøgelse B8, 32-37.

Klemperer, S. L., 1989. Processing of BIRPS deep seismic reflection data: a tutorial review. In Cassinis, R., Nolet, G. \& Panza, G. F. (eds) Digital seismology and fine modelling of the lithosphere. Ettore Majorana International Science Series (Physical Sciences). New York: Plenum Press 42, 229-257.

Klemperer, S. L. \& Hobbs, R. 1991. The BIRPS Atlas. Cambridge University Press, $124 \mathrm{pp}$.

Klemperer, S. L. \& Hurich, C. A. 1990. Lithospheric structure of the North Sea from deep seismic reflection profiling. In Blundell, D. J. \& Gibbs, A. G. (eds) Tectonic evolution of the North Sea Rifts. Oxford University Press, 37-63.

Klinkby, L. \& Pedersen, M. W. (in press). Attenuation of near surface diffracted energy in deep seismic data by DMO correction. Tectonophysics 286.

Michelsen, O. (ed.) 1982. Geology of the Danish Central Graben. Danmarks Geologiske Undersøgelse B8, 135 pp.

Michelsen, O., Frandsen, N., Holm, L., Jensen, T. F., Møller, J. J. \& Vejbæk, O. V. 1987. Jurassic - Lower Cretaceous of the Danish Central Trough; - depositional environments, tectonism, and reservoirs. Danmarks geologiske Undersøgelse serie A16, 45 pp.

Møller, J. J. 1986. Seismic structural mapping of the Middle and Upper Jurassic in the Danish Central Trough. Danmarks geologiske Unders $\emptyset$ gelse A13, $37 \mathrm{pp}$.

MONA LISA Working Group, 1997. MONA LISA - Deep seismic investigations of the lithosphere in the southeastern North Sea. Tectonophysics 269, 1-19.

Newman, P. 1984. Seismic response to sea-floor diffractors. First Break 2, 9-19.

Nielsen, L., Klinkby, L., Balling, N. \& MONA LISA Working Group, 1997. Integrated seismic wide-angle and normal incidence interpretation, MONA LISA Line 3 across the Central Graben, North Sea. Abstract, Annales Geophysicae, Supplement 1 to Volume 15, C68, 244 pp.

Nielsen, L. H. \& Japsen, P. 1991. Deep wells in Denmark 1935-1990. Danmarks geologiske Undersøgelse A31, 179 pp.

Nielsen, S. B. \& Balling, N. 1990. Modelling subsidence, heat flow, and hydrocarbon generation in extensional basins. First Break 8, 23-31.

Noponen, I. \& Keeney, J. 1986. Attenuation of waterborn coherent noise by application of hyperbolic velocity filtering during the tau-p transform. Geophysics 51, 20 33.

Pharaoh, T., England, R. \& Lee, M. 1995. The concealed Caledonide Basement of Eastern England and the Southern North Sea - A review. Studia geophysica et geodaetica 39, 330-346.

Sundsb $\varnothing$, G. O. \& Megson, J. B. 1993. Structural styles in the Danish Central Graben. In Parker, J. R. (ed.) Petroleum Geology of Northwest Europe: Proceedings of the 4th Conference. London: The Geological Society, 12551267.

Vejbæk, O. V. 1986. Seismic stratigraphy and tectonic evolution of the Lower Cretaceous in the Danish Central Trough. Danmarks geologiske Unders $\emptyset$ gelse A11, 46 pp.

Vejbæk, O. V. 1992. Geodynamic modelling of the Danish Central Trough. In Larsen, R. M., Bekke, H., Larsen, B.
T. \& Talleraas, E.(eds) Structural and Tectonic Modelling and its Application to Petroleum Geology. NPF Special Publication 1. Amsterdam: Elsevier, 1-17.

Vejbæk, O. V. \& Britze, P. 1994. Geological map of Denmark. 1:750.000. Top pre-Zechstein. Danmarks geologiske Undersøgelse Map 45.

White, N. J. 1989. Nature of lithospheric extension in the North Sea. Geology 17, 111-114.

Ziegler, P. A. 1990. Geological Atlas of Western and Central Europe. Shell International Petroleum Maatschappij, Amsterdam: Elsevier. 


\section{Erratum}

In the article by Klinkby et al. 'A deep seismic reflection line in the Danish Central Graben' (Bulletin of the Geological Society of Denmark, Vol. 44(2), pp. 151-159, 1998), Tables 1 and 2 were unfortunately omitted. These are printed below.

Table 1. Recording parameters for seismic line DK88-43.

Table 2. Processing parameters for seismic line DK88-43.

\begin{tabular}{|ll|}
\hline Shot points: & $101-1071$ \\
Shot point interval: & $50 \mathrm{~m}$ \\
Airgun array volume: & $5600 \mathrm{cu}$ inch \\
Airgun array pressure: & $1059 \mathrm{psi}$ \\
Array depth: & $8 \mathrm{~m}$ \\
Number of hydrophone groups: & 144 \\
Group interval: & $25 \mathrm{~m}$ \\
Near offset: & $342 \mathrm{~m}$ \\
Far offset: & $3942 \mathrm{~m}$ \\
Streamer depth: & $6 \mathrm{~m}$ \\
Recording time: & $16 \mathrm{~s}$ \\
Sample rate: & $4 \mathrm{~ms}$ \\
Low-cut filter: & $3 \mathrm{~Hz}$ at $6 \mathrm{~dB} /$ oct \\
High-cut filter: & $80 \mathrm{~Hz}$ at $72 \mathrm{~dB} /$ oct. \\
\hline
\end{tabular}

\begin{tabular}{|c|c|}
\hline \multicolumn{2}{|c|}{ Pre-stack } \\
\hline Bandpass filter & $5-50 \overline{\mathrm{Hz}}$ \\
\hline Resample & $8 \mathrm{~ms}$ \\
\hline Mute & \\
\hline NMO, DMO, Invers NMO & one average velocity function \\
\hline Radon filtering & \\
\hline Predictive deconvolution & \\
\hline Operator length & top: $150 \mathrm{~ms}$, bottom $300 \mathrm{~ms}$ \\
\hline $\begin{array}{l}\text { Predictive distance } \\
\text { NMO and CMP-stacking }\end{array}$ & $\begin{array}{l}\text { top: } 32 \mathrm{~ms} \text {, bottom: } 48 \mathrm{~ms} \\
\text { velocity analysis every } 1.5 \mathrm{~km}\end{array}$ \\
\hline \multicolumn{2}{|c|}{ Time migration of entire section } \\
\hline Bandpass filter & $8-30 \mathrm{~Hz}$ \\
\hline Amplitude recovery & $t^{1.5}$ to $7.5 \mathrm{~s} \mathrm{TWT}$ \\
\hline Trace mixing & 5 -traces: $1-2-4-2-1$ \\
\hline Automatic gain control & entire trace length \\
\hline Stolt time migration & \\
\hline Ims-velocities: & $\begin{array}{l}2 \mathrm{~km} / \mathrm{s} \text { at } 0 \mathrm{~s} \mathrm{TWT} \\
4.4 \mathrm{~km} / \mathrm{s} \text { at } 10 \mathrm{~s} T \mathrm{~T}\end{array}$ \\
\hline \multicolumn{2}{|c|}{ Depth migration to $15 \mathrm{~km}$} \\
\hline Bandpass filter & $5-30 \mathrm{~Hz}$ \\
\hline Amplitude recovery & $t^{2}$ to $5 \mathrm{~s} \mathrm{TWT}$ \\
\hline Automatic gain control & entire trace length \\
\hline $\begin{array}{l}\text { Finite difference depth migration } \\
\text { velocities: }\end{array}$ & $\begin{array}{l}70 \text { degrees algorithm } \\
\text { from well logs and } \\
\text { wide-angle data, smoothed field }\end{array}$ \\
\hline
\end{tabular}

